九州大学学術情報リポジトリ

Kyushu University Institutional Repository

\title{
Purification of Neutral Cellulase from a Mixture of Thermophilic Bacilli
}

Kume, Shigeru

Laboratory of Food Processing, Faculty of Agriculture, Kyushu University

Fujio, Yusaku

Laboratory of Food Processing, Faculty of Agriculture, Kyushu University

https://doi.org/10.5109/23966

出版情報: 九州大学大学院農学研究院紀要. 36 (1/2)，pp.37-44，1991-10. Kyushu University バージョン：

権利関係 : 


\title{
Purification of Neutral Cellulase from a Mixture of Thermophilic Bacilli
}

\author{
Shigeru Kume and Yusaku Fujio* \\ Laboratory of Food Processing, Faculty of Agriculture, \\ Kyushu University, 46-09, Fukuoka 812, Japan \\ (Received June 17, 1991)
}

\begin{abstract}
Neutral cellulase was purified from a culture of mixed thermophilic bacilli. After purification, its mol weight was found to be $42 \mathrm{KDa}$, composed of two subunits of $22 \mathrm{KDa}$ and $20 \mathrm{KDa}$, by SDS-PAGE. The activity of this neutral cellulase was optimum at $\mathrm{pH} 7$ and $60^{\circ} \mathrm{C}$ and stable at a $\mathrm{pH}$ range of 5 to 10 and up to $65^{\circ} \mathrm{C}$. The cellulase could hydrolyze some insoluble celluloses although the activity was not so powerful.
\end{abstract}

\section{INTRODUCTION}

There are many microorganisms which have been classified as cellulolytic and some comprehensive reviews on cellulase production have been published, such as that of a recent paper by Kosaric et al. (1983). It was also known that thermophilic microorganisms often produce thermostable enzymes. When a mixture of 11 kinds of thermophilic bacilli (isolates from a sewage sludge compost) was cultured on a medium containing municipal sewage and filter paper, it was found that two types of thermophilic cellulases and three types of proteases appeared in the culture liquid. Some properties regarding the above cellulases (Kume and Fujio, 1991) and proteases (Fujio and Kume, 1991) were already reported by using crude enzyme solution.

The present paper is concerned with the purification and some properties of a neutral cellulase from the above mentioned mixed culture of 11 thermophilic bacilli.

\section{MATERIALS AND METHODS}

\section{Cellulase source}

Crude cellulase was obtained from the culture liquid of 11 bacteria by the same methods described by Kume and Fujio (1991), wherein a neutral and 3 alkaline cel. lulases, and 3 types of proteases have previously been identified.

\section{Purification of cellulase}

The crude cellulase was applied on a Sephacryl S-200 column $(1.8 \times 100 \mathrm{~cm})$, equilibrated with potassium phosphate buffer $(0.05 \mathrm{M}, \mathrm{pH} 7.5)$. Then, the obtained cellulase fraction was re-applied on a hydroxylapatite column $(2.6 \times 30 \mathrm{~cm})$, and eluted stepwisely with $0.02,0.08,0.16$ and $0.40 \mathrm{M}$ phosphate buffers $(\mathrm{pH} 7)$. The fractions with cellulase activity was collected and subsequently purified on a Sephadex G-100 column $(1.8 \times 100 \mathrm{~cm})$, equilibrated with potassium phosphate buffer $(0.05 \mathrm{~m}, \mathrm{pH} 7.5)$.

\footnotetext{
*Correspondent
} 


\section{Cellulase assay}

Cellulase activity was determined on CMC as substrate by the assay of reducing sugar released from CMC by the method of Horikoshi et al. (1983). The activites on various substrates, i. e. filter paper (as FPase), Avicel (as Avicelase), laminaran and cotton were also measured by the methods described by Mandels et al. (1976). On those substrates, unless otherwise stated, cellulase activity was assayed at $\mathrm{pH} 7.0$ (potassium phosphate buffer, $\mathrm{pH} 7,0.1 \mathrm{M}$ ) and at $60^{\circ} \mathrm{C}$ for $10 \mathrm{~min}$.

\section{Dependencies on $\mathbf{p H}$ and temperature}

The following buffer $(0.1 \sim)$ systems were used to measure activity dependency on $\mathrm{pH} ; \mathrm{CH}_{3} \mathrm{COOH}-\mathrm{CH}_{3} \mathrm{COONa}, \mathrm{pH}$ 4-6; $\mathrm{KH}_{2} \mathrm{PO}_{4}-\mathrm{K}_{2} \mathrm{HPO}_{4}, \mathrm{pH}$ 6-8; $\mathrm{KH}_{2} \mathrm{PO}_{4}-\mathrm{Na}_{2} \mathrm{~B}_{4} \mathrm{O}_{7}$, pH8-9; and $\mathrm{Na}_{2} \mathrm{~B}_{4} \mathrm{O}_{7}-\mathrm{NaOH}, \mathrm{pH}$ 9-12. For optimum $\mathrm{pH}$ measurements, cellulase activity was assayed at a desired $\mathrm{pH}(0.05 \mathrm{M})$, ranging from 5-11. In the case of $\mathrm{pH}$ stability, $4 \mathrm{ml}$ of cellulase solution was added into $4 \mathrm{ml}$ of buffer (0.1 ) at a desired $\mathrm{pH}$ and placed at $4^{\circ} \mathrm{C}$ for $24 \mathrm{~h}$. Thereafter, cellulase activity was determined at $\mathrm{pH} 7$ and $60^{\circ} \mathrm{C}$ for $10 \mathrm{~min}$.

The optimum temperature of cellulase was determined at $\mathrm{pH} 7$ at a desired temperature range of $40 \sim 75^{\circ} \mathrm{C}$. In the case of temperature stability, the cellulase solution at $\mathrm{pH} 7$ was placed at a desired temperature ranging from $40-75^{\circ} \mathrm{C}$ for $20 \mathrm{~min}$. Thereafter, cellulase activity was assayed at $\mathrm{pH} 7$ and $60^{\circ} \mathrm{C}$.

Homogeneity and molecular weight

The homogeneity and molecular weight of purified cellulase was estimated with PAGE or SDS-PAGE (Weber and Osbone 1969). Protein bands were detected by staining with coomassie blue or silver stain (Merril, et al. 1981).

Dependencies on metal ions

A $0.1 \mathrm{ml}$ of metal salt solution and $0.5 \mathrm{ml}$ CMC solution $(1 \%$ w/v) in buffer (phosphate buffer, $\mathrm{pH} \mathrm{7,0.05} \mathrm{)} \mathrm{were} \mathrm{mixed} \mathrm{with} 0.1 \mathrm{ml}$ cellulase solution (final metal concentration was adjusted to $25 \mathrm{~mm}$ ) for $\mathrm{KCl}, \mathrm{MaCl}$ and to $1 \mathrm{~mm}$ for $\mathrm{ZnSO}_{4}, \mathrm{CuCl}_{2}$, $\mathrm{CaCl}_{2}, \mathrm{BaCl}_{2}$, and $\mathrm{PCMB}$ ). The cellulase activity was assayed with the desired metal ion.

Substrate specificity of purified neutral cellulase

In accordance with cellulase activity assay, the hydrolysis of various substrates (CMC, filter paper, Avicel, cotton and laminaran) by the neutral cellulase were determined.

\section{Protein assay}

Protein concentration was estimated by using Bio-Rad protein assay system (BioRad Laboratories Japan) with gamma-globulin as a standard.

Chemicals and reagents

All chemicals and reagents were of analytical grade purchased from Nakarai Chemicals Co. Ltd. (Osaka, Japan). 


\section{RESULTS}

\section{Purification of cellulase}

It has been already found by Kume and Fujio (1991) that the crude cellulase preparation contained two types of cellulases with optimum pHs of 7 and 10. Then, the activity profiles were determined at both pHs. Figure 1 shows an elution profile of the crude cellulase preparation by Sephacryl S-200 column chromatography. In accordance with the chromatogram, the cellulases were collected as Fraction I (tubes, 2560) having both cellulase activity at $\mathrm{pH} 7.0$ and 10.0 and Fraction II (tubes, 70-80) with the activity at $\mathrm{pH} 10$.

\section{Hydroxylapatite column chromatography of fraction I}

Figure 2 shows the elution profile of fraction I by hydroxylapatite column chromatography, eluted stepwisely with $0.02,0.08$ and $0.16 \mathrm{M}, \mathrm{pH} 7.0$ phosphate buffer.

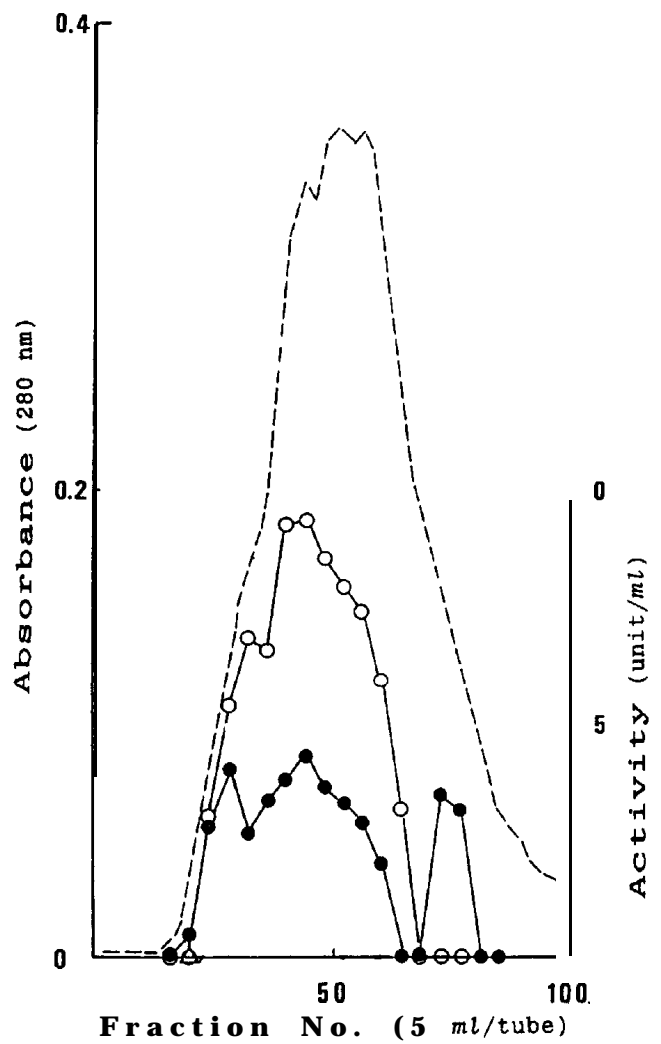

Fig. 1. Sephacryl S-ZOO gel filtration of crude cellulase

Crude cellulase was applied on a Sephacryl S-200 column $(1.8 \times 100 \mathrm{~cm})$ equilibrated with $0.05 M$ phosphate buffer $(\mathrm{pH} 7.5)$ at a flow rate of $15 \mathrm{ml} / \mathrm{h}$. Cellulase activity was determined on $\mathrm{CMC}$ as substrate at $60{ }^{\circ} \mathrm{C}$ for $10 \mathrm{~min}$ using $0.01 \mathrm{M}$ phosphate buffer (pH $7: 0$ ) or $0.01 M$ boric acid- $\mathrm{NaOH}$ buffer $(\mathrm{pH} 10: \bullet)$. 
The fraction (neutral cellulase fraction) eluted with 0.08 м phosphate buffer shows only one cellulase with the $\mathrm{pH} 7$ activity, while other fractions (eluted with 0.04 and $0.16 \mathrm{M}$ of the above buffer) contained both $\mathrm{pH} 7$ and 10 activities.

\section{Sephadex G-100 column chromatography of pH 7 fraction}

The neutral cellulase fraction was subjected to Sephadex G-100 column chromatography and Fig. 3 shows the elution profile. The fraction with $\mathrm{pH} 7$ activity gave a single peak with the same protein peak. This peak was collected as the purified neutral cellulase.

\section{Homogeneity and molecular weight of $\mathrm{pH} 7$ cellulase}

The homogeneity of neutral cellulase was confirmed with PAGE as shown by a single protein band obtained (Fig. 4-A, b). But subjecting the neutral cellulase to SDSPAGE, two protein bands were obtained from it (Fig. 4-B, d). Comparing with

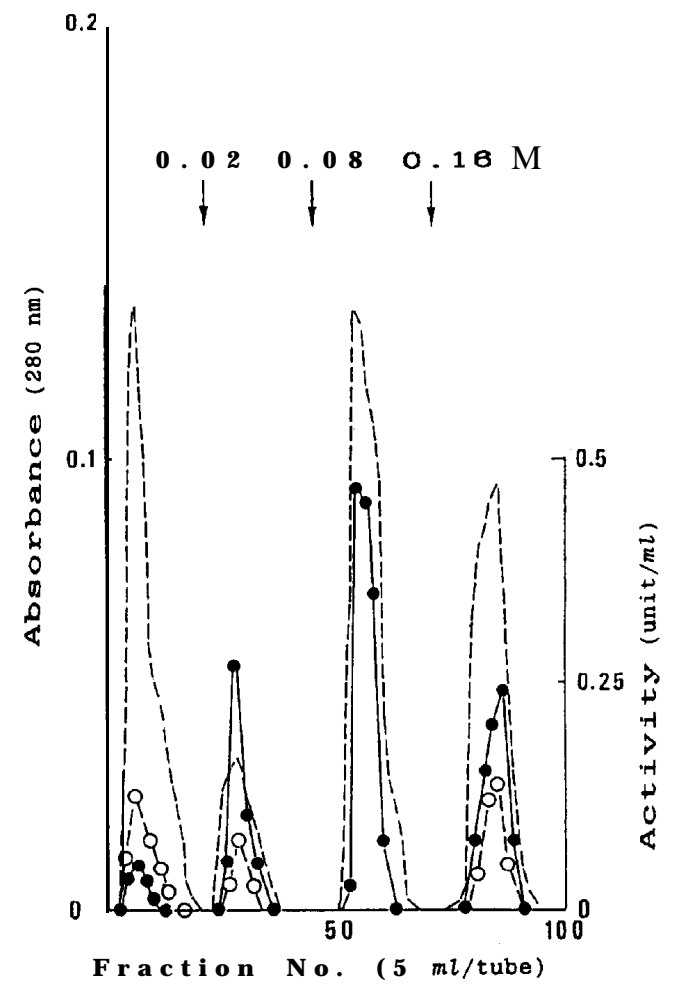

Fig. 2. Hydroxylapatite column chromatography

Hydroxylapatite column $(2.6 \times 30 \mathrm{~cm})$ was washed with $0.02,0.08,0.16$ and $0.40 \mathrm{M}$ phosphate buffer $(\mathrm{pH} 7)$ at a flow rate of $10 \mathrm{ml} / \mathrm{h}$. Cellulase activity was determined on CMC as substrate at $60^{\circ} \mathrm{C}$ for $10 \mathrm{~min}$ using $0.01 \mathrm{M}$ phosphate buffer $(\mathrm{pH} 7: \bullet)$ or $0.01 M$ boric acid- $\mathrm{NaOH}$ buffer $(\mathrm{pH} 10: 0)$. Broken line indicates absorbance at 280 $\mathrm{nm}$. 
standard proteins of known molecular weight, the neutral cellulase gave a molecular weight of $42 \mathrm{KDa}$ may be composed of two subunits of $22 \mathrm{KDa}$ and $20 \mathrm{KDa}$.

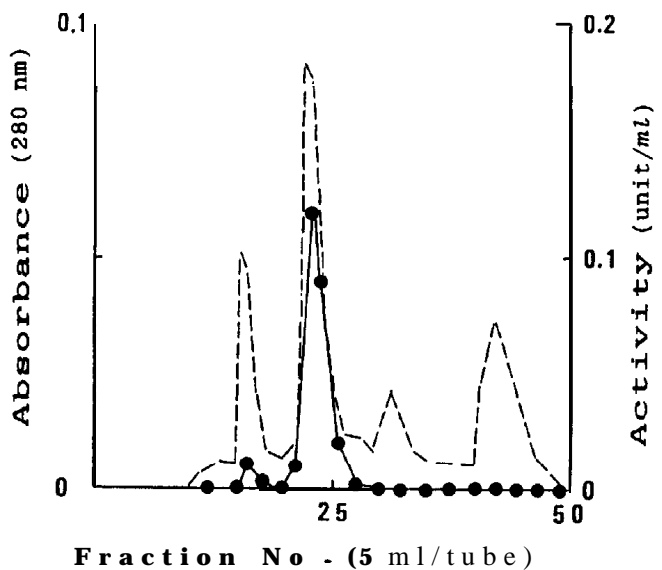

Fig. 3. Sephadex G-100 gel filtration of $0.08 M$ fraction of hydroxylapatite chromatography

Sephadex G-100 $(1.8 \times 100 \mathrm{~cm})$ equilibrated with $0.05 M$ phosphate buffer $(\mathrm{pH} 7.5)$ at a flow rate of $15 \mathrm{ml} / \mathrm{h}$. Cellulase activity was determined on CMC as substrate at $60^{\circ} \mathrm{C}$ for $10 \mathrm{~min}$ using $0.01 \mathrm{M}$ phosphate buffer $(\mathrm{pH} 7: \bullet)$. Broken line indicates absorbance at $280 \mathrm{~nm}$.

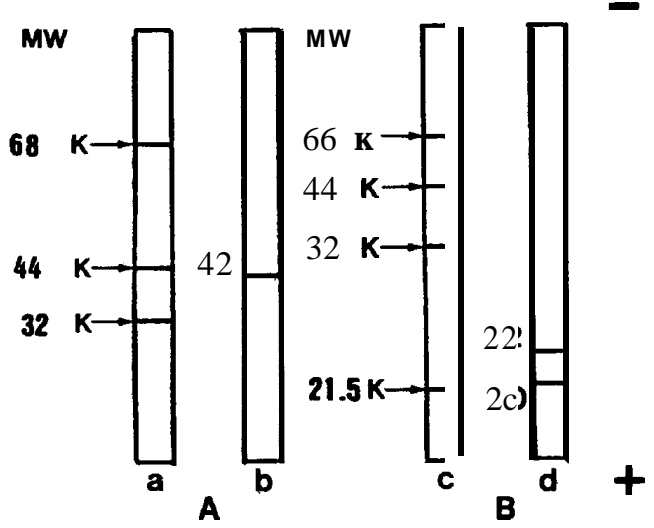

Fig. 4. PAGE and SDS-PAGE of purified cellulase

PAGE (A) containing 7.5\% polyacrylamide was done on lane a (standard proteins of BSA, 68 ; ovalbumin, 44 ; carbonic anhydrase, 32 ; and soybean trypsin inhibitor, 21, 5 $\mathrm{KDa}$ ) and $\mathrm{b}$ (purified cellulase).

SDS-PAGE (B) containing $11 \%$ polyacrylamide and $0.1 \%$

SDS was done on lane $\mathrm{c}$ (the same standard proteins as lane a) and $\mathrm{d}$ (purified cellulalse) 


\section{Summary of pH 7 cellulase purification}

Table 1 summarizes the purification results regarding neutral cellulase. Based on the specific activity, the cellulase was purified by 16 folds based on the crude cellulase.

\section{Effect of $\mathrm{pH}$ and temperature on neutral cellulase activity}

Figure 5 (A and $\mathrm{B}$ ) shows the $\mathrm{pH}$ and temperature dependencies of the neutral cellulase (purified). The optimum reaction $\mathrm{pH}$ and temperature were at $\mathrm{pH} 7$ and at $60^{\circ} \mathrm{C}$, respectively while the $\mathrm{pH}$ and temperature stabilities were at a $\mathrm{pH}$ range of $5^{-}$ 10 and up to $65^{\circ} \mathrm{C}$, respectively.

Effect of metal ions on the activity and substrates specifity of neutral cellulase

Table 2 summarizes the effect of various metal ions on the activity of neutral cellulase. The cellulase activity was increased with $\mathrm{Ca}^{+2}(+12 \%), \mathrm{Ba}^{2+}(+17 \%), \mathrm{Na}^{+}$ $(+29 \%)$ and $\mathrm{K}^{+}(+10 \%)$ but was decreased with $\mathrm{Hg}^{2+}(-21 \%), \mathrm{Zn}^{2+}(-19 \%)$ and $\mathrm{Pb}^{2+}(-16 \%)$.

Table 3 shows the neutral cellulase activities on various substrates. The cellulase could hydrolyze every substrate used. As shown in Table 3, neutral cellulase could decompose solid cellulose. However, the activity on cotton was considerably low comparing with that on $\mathrm{CMC}$ or laminaran as soluble cellulolytic substrates.

\section{DISCUSSION}

Eleven bacilli were isolated from a sewage sludge compost (Kume and Fujio, 1990). As a result of a survey of sewage sludge Iytic enzymes, a neutral and 3 alkaline cellulase, and 3 type of proteases were produced in culture liquid from 11 thermophilic bacilli (Kume and Fujio, 1991 ; Fujio and Kume, 1991). Among those cellulases, only neutral cellulase could be purified as a single protein and characterized in this paper. Comparing this neutral cellulase with other cellulases (crude cellulase) from mixed

Table 1 Summary of neutral cellulase purification

\begin{tabular}{lcccc}
\hline \multicolumn{1}{c}{ Step } & $\begin{array}{c}\text { Volume } \\
(\mathrm{ml})\end{array}$ & $\begin{array}{c}\text { Total } \\
\text { protein } \\
(\mathrm{mg})\end{array}$ & $\begin{array}{c}\text { Total } \\
\text { activity } \\
\text { (unit) }\end{array}$ & $\begin{array}{c}\text { Specific } \\
\text { activity } \\
\text { (unit/mg protein) }\end{array}$ \\
\hline $\begin{array}{l}\text { Culture } \\
\text { liquid }\end{array}$ & 1,000 & 1,280 & 330 & 0.26 \\
$\begin{array}{l}\text { Ethanol ppt } \\
\text { dialyzate }\end{array}$ & 270 & 500 & 149 & 0.30 \\
$\begin{array}{l}\text { Sephacryl } \\
\text { s-200 }\end{array}$ & 100 & 34.4 & 26 & 0.76 \\
$\begin{array}{l}\text { Hydroxyl- } \\
\text { apatite }\end{array}$ & 45 & 1.8 & 8 & 4.50 \\
$\begin{array}{l}\text { Sephadex } \\
\text { G-100 }\end{array}$ & 15 & 1.2 & 5 & 4.25 \\
\hline
\end{tabular}



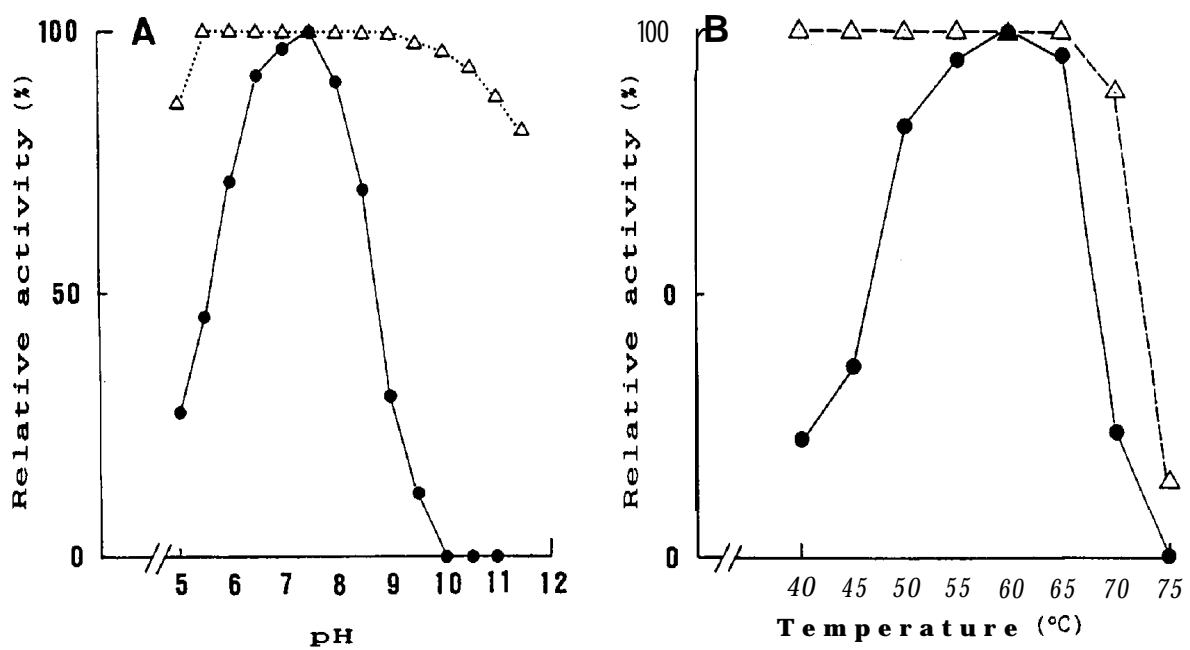

Fig. 5. Effects of $\mathrm{pH}(\mathrm{A})$ and temperature (B) on purified cellulase activity

(A) : Cellulase activity $(\bullet)$ was determined on $\mathrm{CMC}$ as substrate using $0.05 M$ phosphate buffer (pH6-8), $0.05 \quad M \mathrm{KH}_{2} \mathrm{PO}_{4}-\mathrm{Na}_{2} \mathrm{~B}_{2} \mathrm{O}_{7}$ buffer (pH 8-9) and $0.05 \quad M \mathrm{Na}_{2} \mathrm{~B}_{4} \mathrm{O}_{7}-$ $\mathrm{NaOH}$ buffer $\left(\mathrm{pH}\right.$ 9912). Cellulase activity $(\triangle)$ was determined after holding at $4{ }^{\circ} \mathrm{C}$ for $24 \mathrm{~h}$ in the above buffers.

(B) : Cellulase activity ( $\bullet$ ) was determined on CMC as substrate at the indicated temperature for $10 \mathrm{~min}$.

Cellulase stability $(\triangle)$ was determined after holding at the indicated temperature for $20 \mathrm{~min}$.

Table 2 Effect of metal ions on neutral cellulase activity

\begin{tabular}{|c|c|c|}
\hline Metal ion & $\begin{array}{c}\text { Concentration } \\
\text { (mM) }\end{array}$ & $\begin{array}{l}\text { Relative neutral } \\
\text { Cellusase activity } \\
(\%)\end{array}$ \\
\hline None & & 100 \\
\hline $\mathrm{KC} 1$ & 25 & 110 \\
\hline $\mathrm{NaCl}$ & 25 & 129 \\
\hline $\mathrm{ZnCl}$ & 1 & 81 \\
\hline $\mathrm{Pb}\left(\mathrm{CH}_{3} \mathrm{COO}\right)_{2}$ & 1 & 84 \\
\hline $\mathrm{CuCl}_{2}$ & 1 & 116 \\
\hline $\mathrm{CaCl}_{2}$ & 1 & 112 \\
\hline $\mathrm{BaCl}_{2}$ & 1 & 117 \\
\hline $\mathrm{MgCl}_{2}$ & 1 & 98 \\
\hline PCMB' & 1 & 79 \\
\hline
\end{tabular}

bacterial culture (Kahn, 1977; Kahn et al. 1981), it seems that the present cellulase could be more tolerable to higher temperature. In comparison with other bacterial cellulases (Beguin et al., 1977 ; Reynolds et al., 1986 ; Sissons et al., 1987), the present neutral cellulase shows some similarity to that of Clostridium thermocellum or 
Table 3 Purified neutral cellulase activity on various substrates

\begin{tabular}{lcc}
\hline Substrate & $\begin{array}{c}\text { Activity at } \mathrm{pH} 7 \\
\text { (unit) }\end{array}$ & $\begin{array}{c}\text { Activity/CMC } \\
\text { activity } \\
(\%)\end{array}$ \\
\hline CMC' & 69.6 & 100 \\
Filter paper & 0.27 & 0.39 \\
Avicel & 0.16 & 0.23 \\
Cotton & 0.03 & 0.04 \\
Laminaran & 0.42 & 0.60 \\
\hline
\end{tabular}

1) Carboxylmethylcellulose

1 unit $=1 \mu \mathrm{mol}$ glucose released per $\mathrm{h}$

Cellulomonas with regards to their optimum $\mathrm{pH}$ and temperature while the characteristics of any other bacterial cellulases are considerably different.

\section{REFERENCES}

Beguin, P., H. Eisen and A. Roupas 1997 Free and cellulose bound cellulases in a Cellulomonas sp., J. Gen. Microbiol., 101 : 191-196

Fujio, Y and S. Kume 1991 Characteristics of a highly thermostable neutral protease produced from Bacillus stearothermophilus. World J.Microbiol. Biotechnol., 7:12-16

Horikishi, K., M. Nakao, Y. Kurono and N. Sashihara 1983 Cellulase of an alkalophilic Bacillus strain isolated from soil. Canadian J.Microbiol., 30 : 383-389

Kahn, A. W. 1977 Anaerobic degradation of cellulose by mixed culture. Canadian J. Microbiol., 23 : 1700-1705

Kahn, A. W., D. Wall and L. van den Berg 1981 Fermentative conversion of cellulose to acetic acid and cellulolytic enzymes production by a bacterial mixed culture obtained from sewage sludge. Appl. Environ. Microbiol., 41: 1214-1218

Kosaric, N., A. Wieczorek, G. P. Cosentino, R. J.Margee and J. E. Prenosil, Ethanol fermentation, Ethanol from cellulosic materials, Ch. 3a, Biosynthesis of cellulases. In Biotechnology, ed. by Rhem, H. J. and G. Reed, Vol. 3, Verlag Chemie Gmbh, Weinheim, Deerfield Beach, Floridạ, Base1 (1983), p. 309-314

Kume, S. and Y. Fujio 1990 Digestion of municipal sewage sludge by a mixture of thermophilic bacilli and their culture extract. J. Gen. Appl. Microbiol., $36: 189-194$

Kume, S. and Y. Fujio 1991 Production of Two Types of Thermophilic Cellulases in A Mixture of Thermophilic Bacilli. J. Gen. Appl.Microbiol., 3'7 : 25-34

Mandels, M., R. Andreotti and C. Roche 1976 Measurement of saccharifying cellulase. Biotechnol. Bioeng., Symposium No. $6: 21-23$

Merril, C. R., D. Goldman, S. A. Sedman and M. H. Ebert 1981 Ultrasensitive stain for proteins in polyacrylamide gels shows regiol variation in cerebrospinal fluid proteins. Science, 211, 1437-1438

Reynolds, P. H., C. H. Sissons, R. M. Daniel and H. W. Morgan 1986 Comparison of cellulolytic activities in Clostidium thermocellum and three thermophilic cellulolytic anaerobes. Appl. Environ. Microbiol., $51: 12-17$

Sissons, C. H., K. R. Sharrock, R. M. Daniel and H. W. Morgan 1987 Isolation of cellulolytic anaerobic extreme thermophiles from New Zealand thermal sites. Appl. Environ. Microbiol., $51: 12-17$

Weber, K. and M. Osbone 1969 The reliability of molecular weight determination by dodecyl sulfate polyacrylamide gel electrophoresis. J. Biol. Chem., $244:$ 4406-4412 